\title{
Numerical Analysis on Tensile Properties of Grout-filled Splice Sleeve Rebars under ISO 834 Standard Fire
}

\author{
Yong Jun LIU, Chao LI, When Jun ZHOU \\ School of Civil Engineering, Shenyang Jianzhu University, Shenyang, Liaoing 110168, China
}

\begin{abstract}
This paper presents some numerical simulation results of tensile properties of reinforcing bars spliced by grout-filled coupling sleeves under fire conditions to identify the effect of load ratio on fire resistance time of spliced reinforcing bars, which provide a useful base for predicting structural behaviors of pre-cast reinforced concrete buildings in fires. A spliced rebar system investigated in this paper consists of two equal-diameter steel reinforcing bars with $25 \mathrm{~mm}$ diameter and a straight coupling sleeve with $50 \mathrm{~mm}$ outer and $45 \mathrm{~mm}$ inner diameters. As a result, the thickness of grout between steel bars and sleeves are $20 \mathrm{~mm}$. Firstly, the temperature distributions in steel bars connected by grout- filled coupling sleeves exposed to ISO 834 standard fire were calculated utilizing finite element analysis software ANSYS. Secondly, the stress changes in heated steel bars connected by grout-filled coupling sleeves under different constant tensile loads were calculated step by step until the rebar system failed due to fire. Thus, the fire resistant time of rebar spliced by grout-filled coupling sleeves under different axial tensile loads can be determined, further, the relationship between fire resistance time and axial tensile loads ratio can could be obtained. Finally, the fire resistant times versus axial tensile load ratios curve of grout-filled splice sleeve rebars exposed to ISO 834 standard fire is presented.
\end{abstract}

\section{Introduction}

In the late 1960s, Dr. Alfred Alphonse YEE invented grout-filled splice sleeve (vide Figure 1) in Hawaii and got some patents successively. In 1973, grout-filled splice sleeves were first used in precast concrete column-tree connections for 38 stories high Ala Moana Hotel, Honolulu, Hawaii. From then on, the use of grout-filled splice sleeve has been significantly

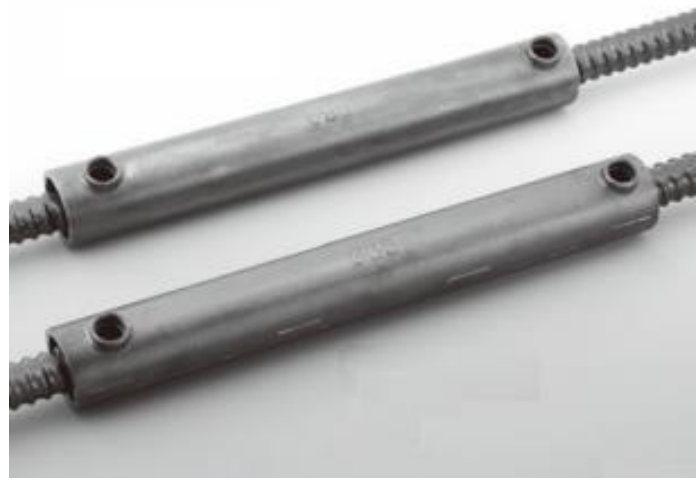

Figure 1 Splice Sleeves and bars before Grout-filling

Up to the present, a large number of studies focus on structural behavior of precast concrete structures splicing reinforcing bars in adjacent two precast components with grout-filled sleeves [1,2]. In March 2011, all buildings using NMB Splice Sleeves in the Tohoku area withstood increasing in precast concrete components worldwide due to their reliability, quality, and durability. The connections between two precast components are key positions for ensuring the integrity of the completed structure under such hazard conditions as earthquake, fire, exploration, and flood, et al, confronted during whole life cycle. Grout-filled sleeves are currently being used widely to splice reinforcing bars of the adjacent two precast components (vide Figure 2).

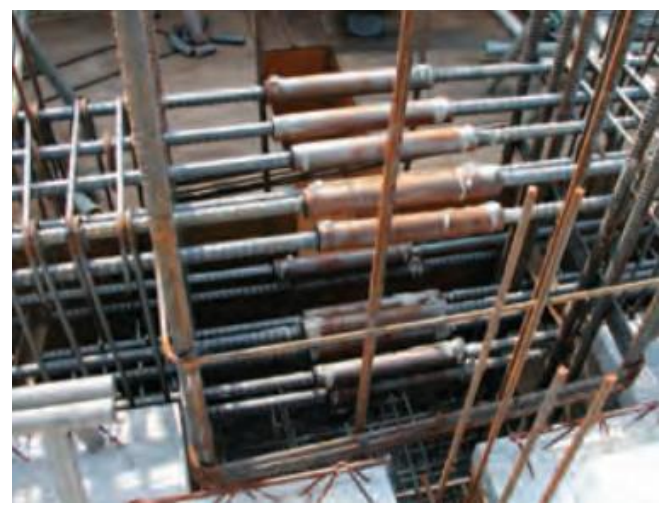

Figure 2 Grout-filled Sleeves Connecting Bars the 9.0 Richter scale earthquake without any structural damage, that demonstrated the high reliability of splice sleeves. It is well known that fires could damage concrete components severely (vide Figure 3) even result in total collapse of whole structures (vide Figure 4) [3-5].

* Corresponding author: ceyjliu@sjzu.edu.cn 
Relatively, very few studies on fire behavior of precast reinforced concrete structures were conducted all over the world. It is urgent needed to investigate the fire behavior of precast reinforced concrete structures using

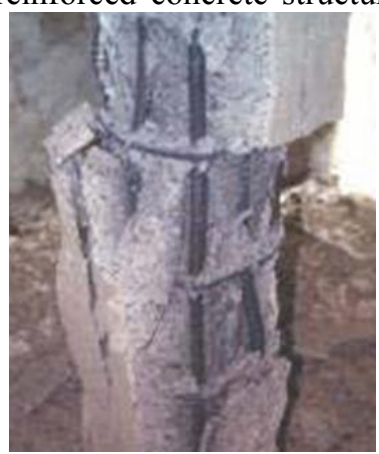

Figure 3 Reinforced Concrete Column Seriously Damaged by Fire

\section{Geometrical Dimensions and Material Properties of the Grout-filled Splice Sleeve}

A spliced rebar system (vide Figure 5) investigated in

(a)

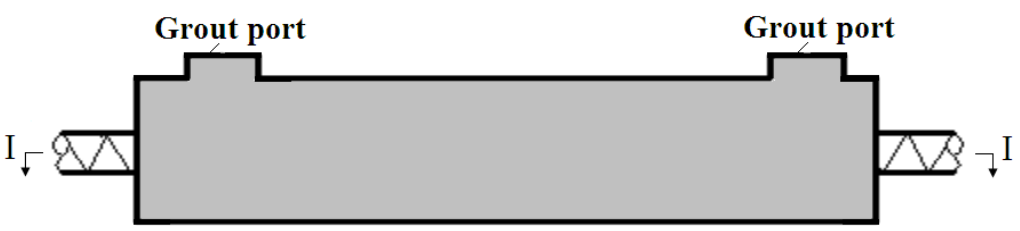

(b)

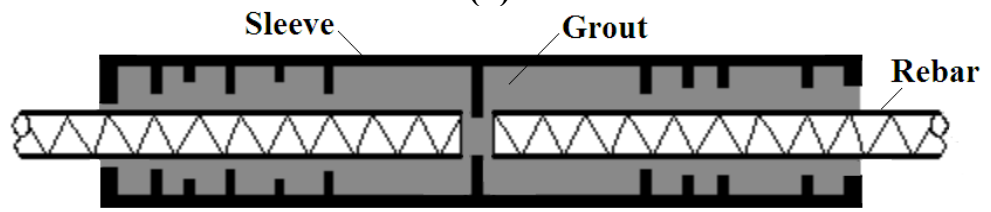

Figure 5 Investigated Spliced Sleeves System: (a)Front View; (b)Section I-I

The investigated spliced sleeves system consists of three kinds of materials, namely, nodular graphite, steel bar, and pouring mortar, the materials thermal and splice sleeves. As a small pilot study, this paper presents some numerical simulation results of tensile properties of reinforcing bars spliced by grout-filled coupling sleeves under fire conditions.

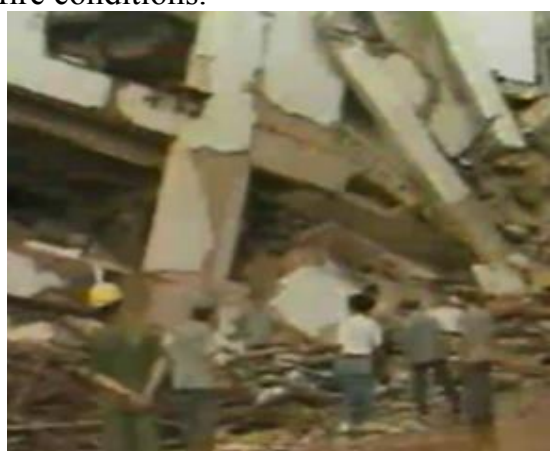

Figure 4 Totally Collapsed Reinforced Concrete Building after Fire

this paper consists of two equal-diameter steel reinforcing bars with $25.0 \mathrm{~mm}$ diameter and a straight coupling sleeve with $50.0 \mathrm{~mm}$ outer and $45 \mathrm{~mm}$ inner diameters. As a result, the thickness of grout between steel bars and sleeves are $20.0 \mathrm{~mm}$. The length of sleeve is $285.0 \mathrm{~mm}$.

Table 1 Material Properties of QTB600-3 Nodular Graphite Cast Iron Changing with Temperature

\begin{tabular}{cccccccc}
\hline $\begin{array}{c}\text { Temperature } \\
T /{ }^{\circ} \mathrm{C}\end{array}$ & $\begin{array}{c}\text { Conductivity } \\
K /\left(\mathrm{W} / \mathrm{m}^{\circ} \mathrm{C}\right)\end{array}$ & $\begin{array}{c}\text { Density } \\
J /\left(\mathrm{kg} / \mathrm{m}^{3)}\right.\end{array}$ & $\begin{array}{c}\text { Specific } \\
\text { Heat } \\
C /\left(\mathrm{J} / \mathrm{kg} \cdot \mathrm{m}^{3}\right)\end{array}$ & $\begin{array}{c}\text { Modulus of } \\
\text { Elasticity } \\
E / \mathrm{GPa}\end{array}$ & $\begin{array}{c}\text { Poisson's } \\
\text { Ratio } \mu\end{array}$ & $\begin{array}{c}\text { Yield } \\
\text { Strength } \\
f_{\mathrm{y}} / \mathrm{MPa}\end{array}$ & $\begin{array}{c}\text { Thermal } \\
\text { Expansion } \\
\alpha /{ }^{\circ} \mathrm{C}^{-1}\end{array}$ \\
\hline 20 & 29.91 & 7300 & 495 & 169.0 & 0.3 & 370 & $1.4 \times 10^{-8}$ \\
100 & 29.79 & 7300 & 511 & 165.1 & 0.3 & 370 & $1.4 \times 10^{-8}$ \\
300 & 29.17 & 7300 & 565 & 158.0 & 0.3 & 298 & $1.4 \times 10^{-8}$ \\
600 & 28.76 & 7300 & 665 & 139.8 & 0.3 & 164 & $1.4 \times 10^{-8}$ \\
$\geq 700$ & 27.65 & 7300 & 924 & 134.6 & 0.3 & 110 & $1.4 \times 10^{-8}$ \\
\hline
\end{tabular}

Table 2 Material Properties of HRB400 Steel Bar Changing with Temperature

\begin{tabular}{cccccccc}
\hline $\begin{array}{c}\text { Temperature } \\
T /{ }^{\circ} \mathrm{C}\end{array}$ & $\begin{array}{c}\text { Conductivity } \\
K /\left(\mathrm{W} / \mathrm{m} \cdot{ }^{\circ} \mathrm{C}\right)\end{array}$ & $\begin{array}{c}\text { Density } \\
J /\left(\mathrm{kg} / \mathrm{m}^{3)}\right.\end{array}$ & $\begin{array}{c}\text { Specific } \\
\text { Heat } \\
C /\left(\mathrm{J} / \mathrm{kg} \cdot \mathrm{m}^{3}\right)\end{array}$ & $\begin{array}{c}\text { Modulus of } \\
\text { Elasticity } \\
E / \mathrm{GPa}\end{array}$ & $\begin{array}{c}\text { Poisson's } \\
\text { Ratio } \mu\end{array}$ & $\begin{array}{c}\text { Yield } \\
\text { Strength } \\
\mathrm{f}_{\mathrm{y}} / \mathrm{MPa}\end{array}$ & $\begin{array}{c}\text { Thermal } \\
\text { Expansion } \\
\alpha / \mathrm{C}^{-1}\end{array}$ \\
\hline 20 & 47.56 & 439.00 & 7850 & 200.0 & 0.3 & 400 & $1.22 \times 10^{-8}$ \\
100 & 45.8 & 487.62 & 7850 & 198.0 & 0.3 & 400 & $1.22 \times 10^{-8}$ \\
\hline
\end{tabular}




\begin{tabular}{cccccccc}
\hline 300 & 41.4 & 564.74 & 7850 & 183.0 & 0.3 & 350 & $1.22 \times 10^{-8}$ \\
$\geq 600$ & 34.8 & 700.00 & 7850 & 34.6 & 0.3 & 177 & $1.22 \times 10^{-8}$ \\
\hline
\end{tabular}

Table 3 Material Properties of Poured Mortar Changing with Temperature

\begin{tabular}{cccccccc}
\hline $\begin{array}{c}\text { Temperature } \\
T /{ }^{\circ} \mathrm{C}\end{array}$ & $\begin{array}{c}\text { Conductivity } \\
K /\left(\mathrm{W} / \mathrm{m}^{\circ}{ }^{\circ} \mathrm{C}\right)\end{array}$ & $\begin{array}{c}\text { Density } \\
J /\left(\mathrm{kg} / \mathrm{m}^{3)}\right.\end{array}$ & $\begin{array}{c}\text { Specific } \\
\text { Heat } \\
C /\left(\mathrm{J} / \mathrm{kg} \cdot \mathrm{m}^{3}\right)\end{array}$ & $\begin{array}{c}\text { Modulus of } \\
\text { Elasticity } \\
E / \mathrm{GPa}\end{array}$ & $\begin{array}{c}\text { Poisson's } \\
\text { Ratio } \mu\end{array}$ & $\begin{array}{c}\text { Yield } \\
\text { Strength } \\
f_{\mathrm{y}} / \mathrm{MPa}\end{array}$ & $\begin{array}{c}\text { Thermal } \\
\text { Expansion } \\
\alpha /{ }^{\circ} \mathrm{C}^{-1}\end{array}$ \\
\hline 20 & 1.8 & 900 & 1800 & 33.0 & 0.3 & 1.725 & $9 \times 10^{-9}$ \\
100 & 1.8 & 900 & 1800 & 32.0 & 0.3 & 1.575 & $9 \times 10^{-9}$ \\
300 & 1.8 & 900 & 1800 & 31.4 & 0.3 & 1.208 & $9 \times 10^{-9}$ \\
$\geq 600$ & 1.8 & 900 & 1800 & 31.4 & 0.3 & 0.69 & $9 \times 10^{-9}$ \\
\hline
\end{tabular}

Finite element models for analyzing temperature

3 Numerical Investigations on Temperature Distribution in Splice Sleeve System

\subsection{Finite Element Mesh}

(a)

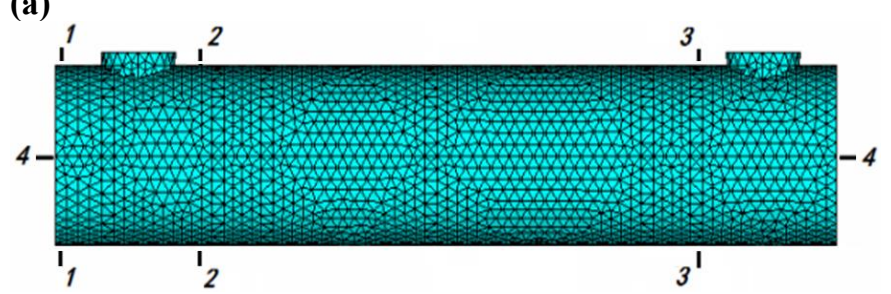

Figure 6 Finite Element Mesh of Grout-filled Splice Sleeve System: (a)Front View; (b)Axonometric Drawing

834 (vide Figure 7) is employed in numerous studies[7].

\subsection{Thermal Boundary and Initial Conditions}

Generally, there are at least two approaches to determine the nominal temperature-time curves of a fire and they incorporate various factors, such as fuel types and ventilation conditions[6]. For simplicity and to facilitate comparison of analysis results from different researchers, standard time-temperature relationship according to ISO utilizing the commercial finite element software ANSYS, in which all parts of the system were divided into 62834 Solid70 elements connecting at 12436 nodes (vide Figure 6). It is worth to note that the rebar were cut and the bottom surfaces of sleeve, mortar, and rebar lie within the same plane for convince.
The temperature-time curve of ISO 834 fire can be described as

$$
T-T_{0}=345 \lg (8 t+1)
$$

In this expression, variables have meanings as: $T\left[{ }^{\circ} \mathrm{C}\right]$ - temperature in the compartment, $t$ [min.] - time, and $T_{0}$ $\left[{ }^{\circ} \mathrm{C}\right]$ - temperature at the start of the fire.

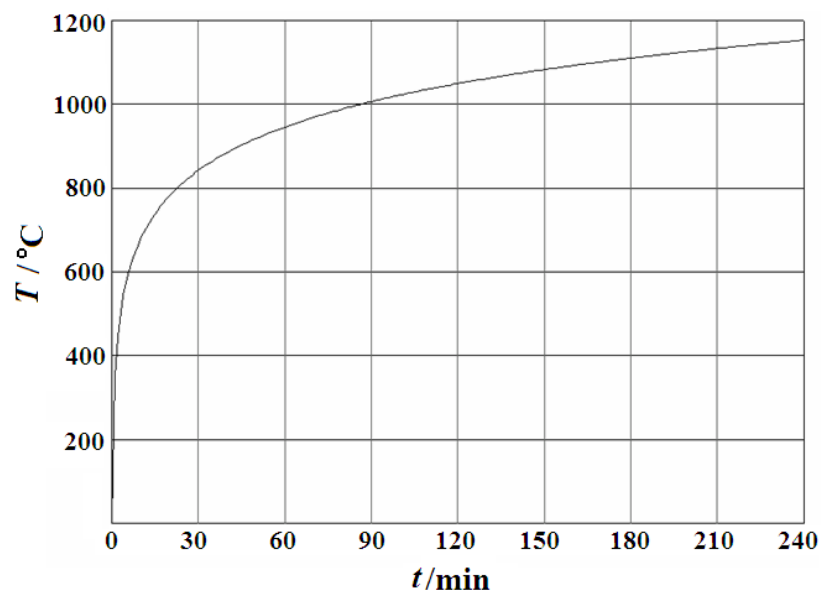

Figure 7 Temperature-time Curve of ISO 834 Fire

The heat flow across the fire-exposed surface is caused by both convection and radiation. Convection coefficient is taken as $28\left(\mathrm{~W} /\left(\mathrm{m}^{2} \cdot \mathrm{K}\right)\right)$, and resultant emissivity is taken as 0.9 . The initial temperature of the spliced rebar system equals to $20^{\circ} \mathrm{C}$. 


\subsection{Finite Element Analysis Results of Temperature Distribution}

Temperature history of nodes in finite element mesh of splice sleeve system under ISO 834 were calculated until the time arrived 180 minutes, which would be used to

(a)

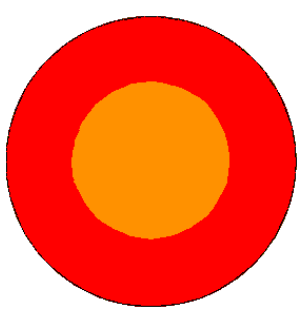

(b)

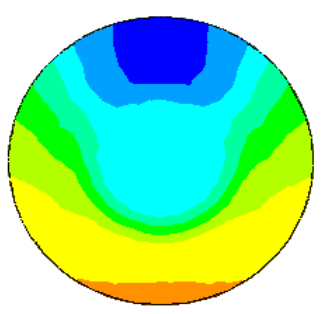

determine temperature-dependent materials properties of splice sleeve system in structural behavior analysis. Contour plots of temperature distribution on four typical sections at $t=7200$ s are shown in Figure 8.

(d)

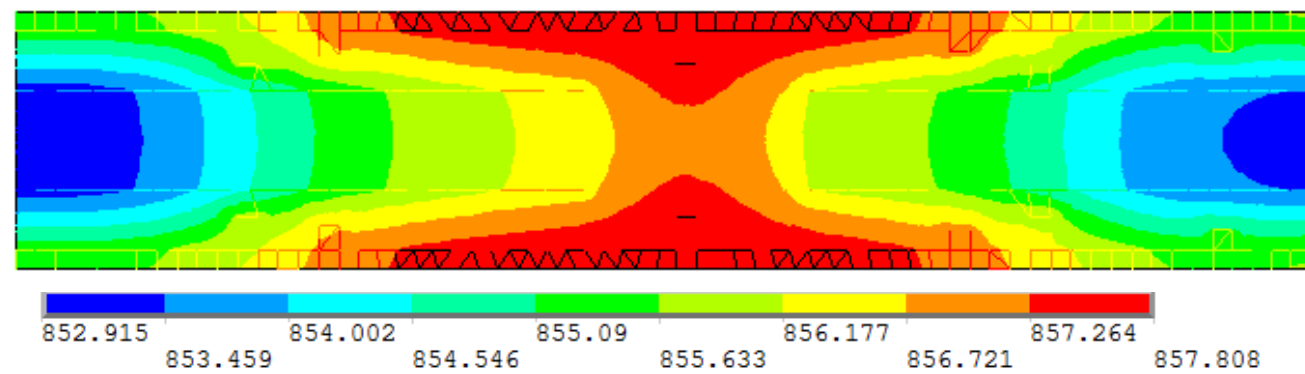

Figure 8 Contour Plots of Temperature Distribution on Four Sections at $t=7200 \mathrm{~s}$ :

(a)Section 1-1; (b)Section 2-2; (c)Section 3-3; (d)Section 4-4

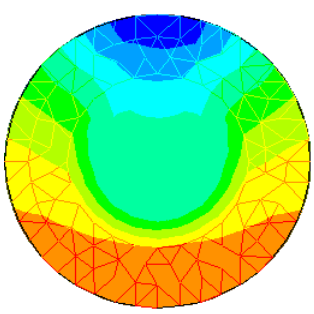

\section{Fire Resistance Time VS Load Ratio Curve}

\subsection{Finite Element Model for Structural Analysis}

After temperature history in splice sleeve system under ISO 834 have been obtained, the structural behavior should be analyzed to determine the fire resistant time of splice sleeve system under different load ratios. The same finite element mesh (vide Figure 6) are used, and Solid45 element were adopted instead of Solid70 element to simulate structural behavior of splice sleeve system. It is assumed that interfaces between sleeve and motor and between motor and rebar are perfectly bonded and no slips are considered.

At room temperature, two identical axial tension loads are applied on the two ends of the sleeve connected rebars, the loads are increased step by step and increment of each step is $20 \mathrm{kN}$, until the splice sleeve system fracture, the total loads are referred to as ultimate loads under room temperature, expressed as $F_{\mathrm{u}}$. For the splice

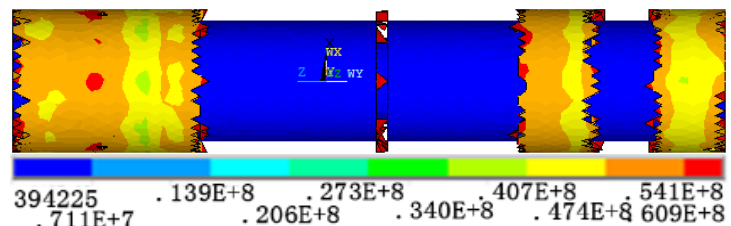

Figure 9 Contour Plots of Von Mises Stress at $t=4200 \mathrm{~s}$, with $L_{\mathrm{r}}=80 \%$ (Unit: MPa) sleeve system investigated in this paper, the $F_{\mathrm{u}}$ equal to $221.00 \mathrm{kN}$.

\subsection{Results of Structural Analysis}

If two identical loads $F_{\mathrm{P}}$, which are less than ultimate load under room temperature, is applied on two ends of rebar in splice sleeve system, then the value of $F_{\mathrm{p}}$ over $F_{\mathrm{u}}$ is called as load ratio, expressed as $L_{\mathrm{r}}$. Obviously, $L_{\mathrm{r}}$ will influence the fire resistance time, $R_{\mathrm{t}}$, of splice sleeve system. Generally, fire resistance time, $R_{\mathrm{t}}$, should decrease with the increase of $L_{\mathrm{r}}$. The main purpose of this paper is to find the relationship between $R_{\mathrm{t}}$ and $L_{\mathrm{r}}$.

Under several load ratios, the fire resistance time, $R_{\mathrm{t}}$, of splice sleeve system is calculated using software ANSYS. Figure 9 and Figure 10 show the Von Mises stress contour and first principal tensile strain at $t=4200 \mathrm{~s}$ with $L_{\mathrm{r}}=80 \%$. Figure 11 shows the relationship curve between $R_{\mathrm{t}}$ and $L_{\mathrm{r}}$. Ones can obtain the fire resistant time of a splice sleeve system under ISO 834 standard fire according to the load ratio via linear interpolation.

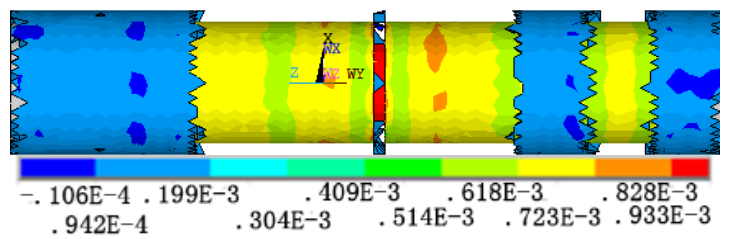

Figure 10 Contour Plots of First Principal Tensile Strain at $t=4200 \mathrm{~s}$, with $L_{\mathrm{r}}=80 \%$ 


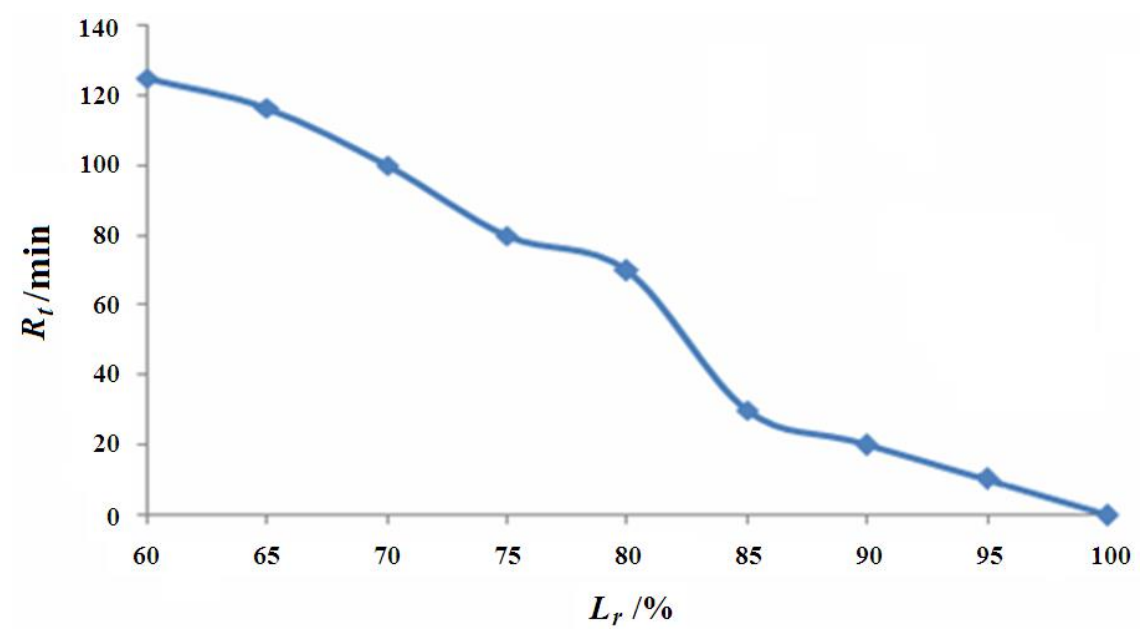

Figure 11 Fire Resistance Time - Load Ratio Relation Curve

\section{Conclusions}

This paper presents some numerical simulation results of tensile properties of reinforcing bars spliced by grout-filled coupling sleeves under fire conditions to identify the effect of load ratio on fire resistant time of spliced reinforcing bars, with the emphasis on relationship curve of between fire resistance times and load ratios. In addition to the spliced rebar system with straight coupling sleeve with $50 \mathrm{~mm}$ outer and $45 \mathrm{~mm}$ inner diameters investigated in this paper, a plenty of spliced rebar system with different sizes have been simulated using software ANSYS. Numerical simulation results indicate that the load ratio has significant effects on fire resistance time of reinforcing bars spliced by grout-filled coupling sleeves. Excessively higher load ratio should be avoided to prevent collapse of precast reinforced concrete buildings in fire conditions. Some complementary tests on fire behavior of reinforcing bars spliced by grout-filled coupling sleeves have been conducted, and results of which will be presented in subsequent papers.

\section{Acknowledgments}

This work is supported by Nature Science Foundation of Liaoning Province of China under grant No. 2015060200.

\section{References}

1. Haber Z B, Saiidi M S, Sanders D H. Seismic performance of precast columns with mechanically spliced column-footing connections[J]. ACI Structural Journal, 2014, 111(3): 639-650.

2. Belleri A, Riva P. Seismic performance and retrofit of precast concrete grouted sleeve connections[J]. PCI Journal, 2012, 57(4): 97-109.

3. Liu Yongjun, Li Hongnan. Review and prospect of the study on behavior of structures in fire conditions $[\mathrm{J}]$. Journal of Disaster Prevention and Mitigation Engineering, 2004, 24(2): 219-226.
4. Huang Z, Andrew P. Nonlinear finite element analysis of planar reinforced concrete members subjected to fires[J]. ACI Structural Journal, 1997, 94(3): 272-282.

5. Mohamad J T. Numerical modeling of the behavior of concrete structures in fire[J]. ACI Structural Journal, 1998, 95(2): 183-193.

6. Tom Lennon, David Moore. The natural fire safety concept - full-scale tests at Cardington[J]. Fire Safety Journal, 2003, 38(7): 623-643.

7. International Organization for Standardization. ISO 834, fire resistance tests elements of building construction[S]. Geneve, 1999. 